\title{
PEMBUATAN DAN UJI KEMAMPUAN MEMBRAN KITOSAN SEBAGAI MEMBRAN ULTRAFILTRASI UNTUK PEMISAHAN ZAT WARNA RHODAMIN B
}

\author{
Nita Kusumawati dan Septiana Tania \\ Jurusan Kimia FMIPA Universitas Negeri Surabaya \\ Jl. Ketintang Surabaya 60231 \\ Email: nitakusumawati82@yahoo.com
}

\begin{abstract}
ABSTRAK
Telah dilakukan penelitian tentang pembuatan membran kitosan dan aplikasinya dalam pemisahan zat warna Rhodamin B. Tujuan penelitian ini adalah untuk mengetahui karakteristik fisik serta kinerja membran kitosan yang dihasilkan dalam memisahkan zat warna Rhodamin B dengan variasi konsentrasi kitosan dan tekanan operasional. Penelitian ini diawali dengan pembuatan membran dengan variasi konsentrasi kitosan, yaitu 1-5\%. Membran kitosan dibuat dengan mencampurkan kitosan dalam asam asetat $1 \%$ kemudian dicetak pada cawan petri. Uji karakteristik fisik membran meliputi, kekuatan tarik dan regangan membran menggunakan Autograph, dan morfologi serta ukuran pori membran menggunakan Scanning Eletron Microscopy (SEM). Kinerja membran meliputi nilai fluks dan rejeksi, diketahui dari pengukuran menggunakan alat uji membran "dead-end" dan UV-Visible Genesys 10. Hasil penelitian menunjukkan bahwa membran kitosan yang dihasilkan masuk dalam rentang membran ultrafiltrasi. Membran memiliki daya tegang dan regang yang tinggi dengan bertambahnya konsentrasi kitosan. Nilai tegangan (Load) yang diperoleh sebesar 0,1531-2,8571 kgf dan nilai regangan (Stroke) sebesar 2,86-5,48\%. Semakin besar konsentrasi kitosan dalam membran akan menghasilkan fluks yang kecil. Nilai fluks terbaik dihasilkan oleh membran kitosan $1 \%$ pada tekanan $5 \mathrm{~kg} / \mathrm{cm}^{2}$ yakni sebesar $38,372 \mathrm{~L} / \mathrm{m}^{2}$.jam. Sedangkan nilai koefisien rejeksi tertinggi dihasilkan oleh membran kitosan $3 \%$ pada tekanan $1 \mathrm{~kg} / \mathrm{cm}^{2}$ yakni sebesar $88,27 \%$.
\end{abstract}

Kata kunci: membran kitosan, ultrafiltrasi, fluks, rejeksi, rhodamin B

\section{PREPARATION AND CAPABILITIES TESTING OF CHITOSAN MEMBRAN FOR RHODAMIN-B SEPARATION}

\begin{abstract}
The research of chitosan membrane design and its application for Rhodamine B separation has been done. The purpose of this study was to determine the physical characteristics and performance of chitosan membranes that produced to separate Rhodamine B by varying the concentration of chitosan and operational pressures. This study begins with the manufacture of membranes with varying the concentration of chitosan, which is $1-5 \%$. Chitosan membranes prepared by mixing chitosan in $1 \%$ acetic acid and then casted on a petri dish. Physical characteristics of the membrane covering the test, tensile strength and tensile membrane using Autograph, and the morphology and pore size membrane using Eletron Scanning Microscopy (SEM). Performance of the membranes covering the value of the flux and rejection, it is known from measurements
\end{abstract}


using "dead-end" reactor membrane and UV-Visible Genesys 10. The results showed that chitosan membrane produced into the range of ultrafiltration membranes. The membrane has a high tensile strain with increasing concentrations of chitosan. Load value obtained at 0.1531 to $2.8571 \mathrm{kgf}$ and the strain (Stroke) of 2.86 to $5.48 \%$. The greater concentration of chitosan in the membrane will produce a small flux. The best value of the flux generated by a $1 \%$ chitosan membrane at a pressure of $5 \mathrm{~kg} / \mathrm{cm}^{2}$ which amounted to 38.372 $\mathrm{L} / \mathrm{m}^{2}$.jam. While the rejection coefficient of the highest value is generated by $3 \%$ chitosan membrane at a pressure of $1 \mathrm{~kg} / \mathrm{cm}^{2}$ which amounted to $88.27 \%$.

\section{Keyword : chitosan membrane, ultrafiltration, flux, rejection, rhodamin-B}

\section{PENDAHULUAN}

Saat ini, sebagian besar industri tekstil menggunakan zat warna sintetis dengan alasan murah, warnanya yang tahan lama, mudah diperoleh dan digunakan tetapi limbah yang dihasilkan masih berwarna dan sulit terdegradasi. Sekitar $15-20 \%$ zat warna yang digunakan akan tersisa pada air buangan yang pada akhirnya akan masuk ke dalam lingkungan sekitarnya (Chatterjee, et al., 2007).

Rhodamin B merupakan salah satu jenis pewarna non azo yang banyak digunakan dalam industri tekstil. Potensi karsinogenik rhodamin B juga perlu mendapatkan perhatian yang serius. Rhodamin B dapat menyebabkan injection site sacromas pada tikus (Umeda, 1956 dalam Fisher $\mathrm{P}$, et al., 1996). Pada penelitian yang dilakukan oleh Bio/Dynamics (1981), peningkatan sel granular tumor otak berhasil diobservasi dari tikus jantan yang mengkonsumsi $0,02 \%$ rhodamin B dalam menu makanannya.

Perkembangan teknologi membran sebagai unit pengolah limbah saat ini sangat pesat dan banyak digunakan dalam proses pemisahan. Operasi membran dapat diartikan sebagai proses pemisahan dua atau lebih komponen dari aliran fluida melalui suatu membran. Membran berfungsi sebagai penghalang (barrier) tipis yang sangat selektif diantara dua fasa, hanya dapat melewatkan komponen tertentu dan menahan komponen lain dari suatu aliran fluida yang dilewatkan melalui membran (Mulder, 1996).

Dalam aplikasinya untuk proses pemisahan, pemurnian dan pemekatan, teknologi membran mempunyai berbagai keunggulan dibandingkan metoda pemisahan yang konvensional, di antaranya proses dapat dilakukan secara kontinyu, tidak memerlukan zat kimia tambahan, konsumsi energi rendah, pemisahan dapat dilakukan pada kondisi yang mudah diciptakan, dapat dilangsungkan pada temperature rendah sehingga dapat digunakan untuk pemisahan senyawa yang tidak tahan temperatur tinggi, mudah dalam scale up, tidak membutuhkan kondisi yang ekstrim ( $\mathrm{pH}$ dan temperatur), material membran bervariasi sehingga mudah diadaptasikan pemakaiannya dan mudah dikombinasikan dengan proses pemisahan lainnya.

Proses membran ultrafiltrasi (UF) merupakan upaya pemisahan dengan membran yang menggunakan gaya dorong beda tekanan, sangat dipengaruhi oleh ukuran dan distribusi pori membran (Malleviale, 1996). Karakteristik struktur membran ultrafiltrasi adalah memiliki ukuran pori antara 0,001-2 $\mu \mathrm{m}$ (Mulder, 1996). Membran ini beroperasi pada tekanan antara 1-5 bar dan batasan permeabilitasnya adalah 10-50 $1 / \mathrm{m}^{2}$.jam.bar. Parameter utama dalam proses pemisahan menggunakan membran yaitu permeabilitas dan permselektivitas. 
Saat ini telah banyak dikembangkan pembuatan membran dari polimer alam dengan alasan polimer alam lebih ramah lingkungan daripada polimer sintetis. Pada umumnya membran yang sering digunakan untuk proses pemisahan adalah membran yang terbuat dari selulosa asetat.

Kitosan merupakan suatu polimer alam yang mempunyai struktur mirip dengan selulosa serta dapat dibentuk menjadi film tipis (Hassan dan Sulaiman, 1996 dalam Meriatna, 2008).

Berdasarkan latar belakang tersebut di atas, pada penelitian ini akan dibuat membran dari kitosan dan diuji coba kemampuan membran tersebut untuk proses pemisahan zat warna rhodamin B. Dalam penelitian ini, membran dibuat dari kitosan yang dilarutkan dalam asam asetat dengan beberapa variasi komposisi tertentu dari kitosan dan pelarutnya. Kemudian diaplikasikan pada alat uji "dead-end" untuk pemisahan zat warna rhodamin B dengan variasi tekanan operasional reaktor membran.

\section{METODE PENELITIAN}

\section{Alat dan Bahan}

Pada percobaan ini digunakan alatalat gelas, antara lain gelas beaker, labu takar, gelas ukur, corong gelas, spatula dan cawan arloji. Pemindahan larutan dilakukan dengan pipet tetes dan pipet volume. Selain itu, alat-alat yang juga digunakan adalah stirer, neraca analitik, kompresor sebagai sumber tekanan, dan cetakan membran menggunakan cawan petri. Instrumen yang digunakan untuk analisis pada penelitian ini, meliputi Scanning Electron Microscope (SEM) JEOL JSM 35C., Autograph, reaktor membran "dead-end" dan spektrofotometri UV-Vis Genesys 10.

Bahan utama yang digunakan dalam penelitian ini adalah kitosan dari kulit udang (Derajat Deasetilasi 80) dan zat warna Rhodamin B. Selain itu bahan analisis dan pembantu yang digunakan meliputi asam asetat $\left(\mathrm{CH}_{3} \mathrm{COOH}\right)$ disediakan oleh Aldrich, Natrium Hidroksida $(\mathrm{NaOH})$ disediakan oleh aldrich dan Aquades.

\section{Prosedur Penelitian}

\section{Pembuatan Membran Kitosan}

Sebanyak 1 gram kitosan dari kulit udang dilarutkan dalam $100 \mathrm{ml} \mathrm{CH}_{3} \mathrm{COOH} 1 \%$ (v/v) pada suhu ruang. Bahan yang telah dicampur diaduk dengan stirer selama 2 jam hingga homogen sehingga diperoleh larutan kitosan $1 \%$, selanjutnya larutan tersebut didiamkan selama \pm 24 jam. Larutan kitosan kemudian dituangkan ke dalam cetakan cawan petri yang sebelumnya telah dibersihkan dengan menggunakan aseton. Membran yang telah dicetak dikeringkan pada suhu kamar. Selanjutnya, ditambahkan larutan $\mathrm{NaOH} 1 \%$ ke dalam film kitosan yang sudah kering dan didiamkan hingga membran terangkat ke permukaan. Untuk menghilangkan $\mathrm{NaOH}$ dilakukan pencucian pada membran secara berulang-ulang menggunakan aquades. Prosedur yang sama juga diterapkan untuk pembuatan membran kitosan dengan konsentrasi kitosan 2, 3, 4 dan $5 \%$.

\section{Aplikasi Membran Pada Alat "dead- end" dan Penetuan Nilai Fluks Pemisahan}

Membran yang akan diuji dipotong berbentuk lingkaran dengan diameter \pm 7 $\mathrm{cm}$. Membran diletakkan di bagian bawah alat penguji yang sebelumnya telah dilapisi dengan kertas saring. Seratus mililiter larutan feed rhodamin B dimasukkan ke dalam alat, ditutup rapat dan kemudian ke dalamnya dialirkan tekanan $1-5 \mathrm{~kg} / \mathrm{cm}^{2}$. Volume permeat yang dihasilkan dicatat setiap 5 menit selama 30 menit. Fluks dapat dihitung dengan menggunakan rumus: 


$$
I=\frac{V}{A x t}
$$

Dimana,

$\mathrm{J}=$ Fluks $\left(1 / \mathrm{m}^{2} . \mathrm{jam}\right)$

$\mathrm{V}=$ Volume permeat $(\mathrm{ml})$

$\mathrm{A}=$ Luas permukaan membran $\left(\mathrm{m}^{2}\right)$

$\mathrm{t}=$ Waktu (jam)

\section{Penentuan Koefisien Rejeksi}

Untuk mengetahui konsentrasi rhodamin B setelah dilewatkan membran, dilakukan pengukuran nilai absorbansi dengan menggunakan instrumen spektrofotometer UV-Visible. Nilai absorbansi yang diperoleh dimasukkan pada persamaan regresi dari kurva kalibrasi, untuk selanjutnya dapat dihitung koefisien rejeksinya. Koefisien rejeksi dapat dihitung dengan menggunakan rumus:

$$
R=1-\frac{C p}{C f} \times 100 \%
$$

Dimana,

$\mathrm{R}=$ Koefisien rejeksi (\%),

$C p=$ Konsentrasi zat terlarut dalam permeat,

$C f=$ Konsentrasi zat terlarut dalam umpan.

\section{HASIL DAN PEMBAHASAN}

\section{Pembuatan Membran Kitosan}

Membran dapat dipreparasi dengan menggunakan beberapa metode antara lain sintering, streaching, track-etching, template leaching dan inversi fasa. Pembuatan membran dalam penelitian ini menggunakan metode inversi fasa. Inversi fasa adalah metode yang paling banyak digunakan dalam pembuatan membran polimer untuk proses pemisahan (Kim dan Lee, 1998). Inversi fasa adalah proses dimana polimer diubah dari bentuk larutan menjadi bentuk padatan secara terkontrol. Proses pemadatan sangat sering diawali dengan perpindahan polimer dari suatu cairan (pelarut) ke cairan lain (non-pelarut). Fase dengan konsentrasi polimer yang tinggi dalam larutan polimer akan membentuk padatan atau matriks membran, sedangkan fase dengan konsentrasi polimer yang rendah akan membentuk pori-pori (Mulder, 1996).

Serbuk kitosan yang akan digunakan sebagai bahan pembuatan membran dilarutkan terlebih dahulu ke dalam asam asetat $1 \%$ karena keterlarutan kitosan yang paling baik ialah dalam larutan asam asetat $1 \%$, asam format $10 \%$ dan asam sitrat $10 \%$. Larutan kitosan sebelum dicetak harus dibiarkan dahulu kurang lebih selama 24 jam untuk menghilangkan gelembung-gelembung udara karena gelembung udara yang terperangkap pada saat pencetakan membran dapat mengakibatkan lubang pada membran, selain itu juga dapat menutupi pori membran.

Untuk melepas membran dari cetakan, diperlukan perendaman dengan larutan $\mathrm{NaOH} 1 \%$. Larutan $\mathrm{NaOH}$ dalam hal ini berfungsi sebagai larutan nonpelarut yang dapat berdifusi ke bagian bawah membran yang berhimpitan dengan permukaan cetakan sehingga membran tersebut akan terdorong ke atas dan terkelupas. Membran yang telah dilepaskan dari cawan petri dicuci berulang-ulang dengan akuades untuk menghilangkan $\mathrm{NaOH}$.

\section{Morfologi Membran}

Untuk mengetahui morfologi membran, digunakan Scanning Electron Microscopy (SEM) yang dapat memberikan informasi mengenai struktur morfologi membran. Dengan SEM, juga dapat diperoleh data mengenai ukuran pori membran, sehingga dari hasil ini dapat ditentukan standar keseragaman struktur membran yang dapat digunakan (Mulder, 1991). Berdasarkan imaging yang diperoleh dari Scanning Elektron Miscroscopy (SEM), dapat diketahui 
Pembuatan dan uji kemampuan membran kitosan... (Nita Kusumawati dan Septiana Tania)

ukuran pori membran, yaitu sebagai berikut: (a) membran kitosan $1 \%$ mempunyai ukuran pori yang dapat teridentifikasi adalah antara 0,6 $\mu \mathrm{m}$ sampai $1,3 \mu \mathrm{m}$, (b) untuk membran kitosan $2 \%$ mempunyai ukuran pori yang dapat teridentifikasi adalah antara $0,4 \mu \mathrm{m}$ sampai 0,6 $\mu \mathrm{m}$ dan (c) membran kitosan $3 \%$ mempunyai ukuran pori yang dapat teridentifikasi adalah antara $0,1 \mu \mathrm{m}$ sampai $0,3 \mu \mathrm{m}$. Dilihat dari ukuran pori, membran yang dihasilkan termasuk membran ultrafiltrasi. Karakteristik struktur membran ultrafiltrasi adalah memiliki ukuran pori antara $0,001 \mu \mathrm{m}-$ $2 \mu \mathrm{m}$ (Mulder, 1996).

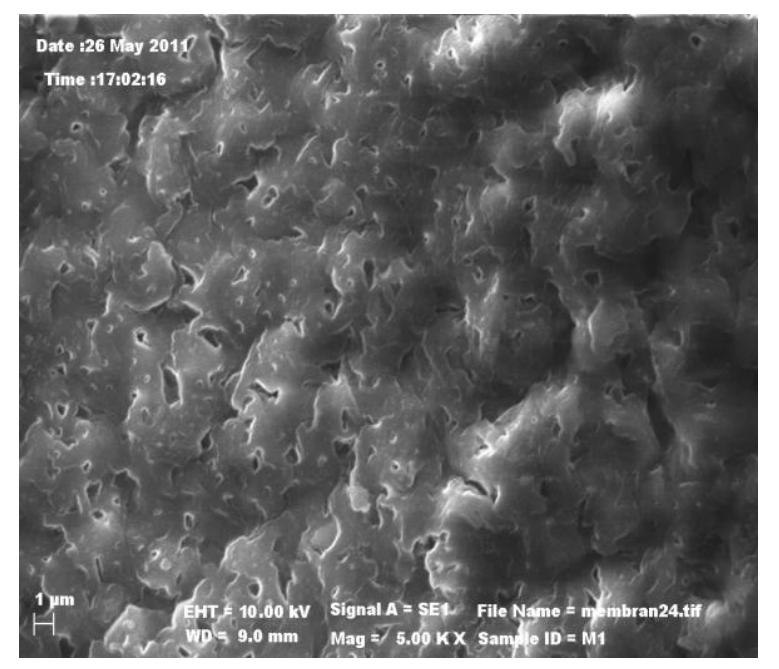

a

\section{Sifat Mekanik Membran Kitosan}

Karakterisasi sifat mekanik perlu dilakukan untuk mengetahui kekuatan membran terhadap gaya yang berasal dari luar, yang dapat merusak membran. Semakin rapat struktur membran, berarti jarak antara molekul dalam membran semakin rapat sehingga mempunyai kekuatan tarik dan jebol yang kuat. Kekuatan tarik membran kitosan dapat dilihat dari nilai Load yaitu nilai kuat tegang membran pada saat putus dan Stroke yaitu kekuatan regangan pada saat putus yang dimiliki oleh membran kitosan.

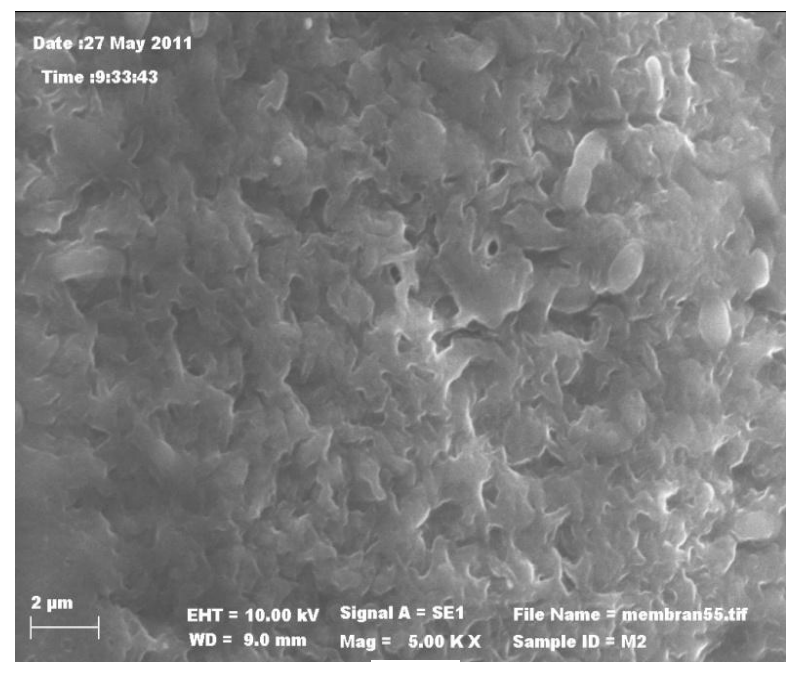

b

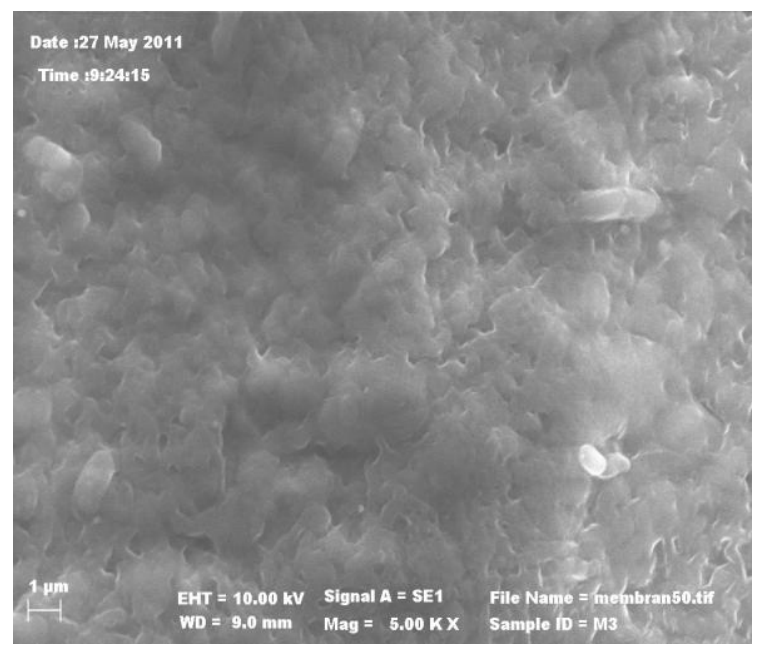

c

Gambar 1. Morfologi membran

(a) Membran Kitosan 1\%; (b) Membran Kitosan 2\%; (c) Membran Kitosan 3\% 
Tabel 1. Data hasil uji kekuatan tarik membran kitosan

\begin{tabular}{|c|c|c|c|}
\hline $\begin{array}{c}\text { Konsentrasi Membran } \\
\text { Kitosan (\%) }\end{array}$ & $\begin{array}{c}\text { Tegangan (Load) } \\
(\mathrm{kgf})\end{array}$ & $\begin{array}{c}\Delta \mathrm{L} \\
(\mathrm{mm})\end{array}$ & $\begin{array}{c}\text { Regangan (stroke) } \\
(\%)\end{array}$ \\
\hline 1 & 0,1531 & 1,72 & 2,86 \\
\hline 2 & 1,5816 & 1,85 & 3,08 \\
\hline 3 & 1,8367 & 2,41 & 4,02 \\
\hline 4 & 2,3980 & 2,68 & 4,47 \\
\hline 5 & 2,8571 & 3,29 & 5,48 \\
\hline
\end{tabular}

Kekuatan tarik pada saat putus (tegangan) meningkat dengan bertambah tingginya konsentrasi membran kitosan. Membran kitosan 4\% dan 5\% memiliki kekuatan tarik yang besar. Hal tersebut dikarenakan strukturnya yang rapat menyebabkan jarak antara molekul dalam membran semakin rapat sehingga mempunyai kekuatan tarik yang besar.

\section{Pengukuran Fluks}

Pengukuran nilai fluks dilakukan untuk mengetahui kemampuan membran dalam melewatkan sejumlah volume umpan. Hal tersebut dikarenakan fluks merupakan standar dalam mengevaluasi kinerja membran sebelum dan sesudah digunakan. Pengukuran nilai fluks dilakukan dengan menampung volume permeat tiap 30 menit dalam gelas ukur.
Dalam pelaksanaan operasi membran digunakan rhodamin B sebagai larutan umpan (feed).

Pada tiap membran yang sama, semakin besar tekanan yang diberikan, akan semakinbesar pula nilai fluks yang dihasilkan. Pada pemberian tekanan 5 $\mathrm{kg} / \mathrm{cm} 2$, dihasilkan fluks yang lebih besar untuk tiap waktu operasi dibandingkan dengan tekanan $1-4 \mathrm{~kg} / \mathrm{cm}^{2}$. Hal ini sesuai dengan gaya dorong utama (driving force) dari operasi membran. Peningkatan tekanan yang diaplikasikan pada aliran umpan yang melewati membran akan menyebabkan terjadinya deformasi pada membran sehingga ukuran pori-pori membran melebar dan fluks yang dihasilkan pun semakin besar seiring dengan pertambahan tekanan.

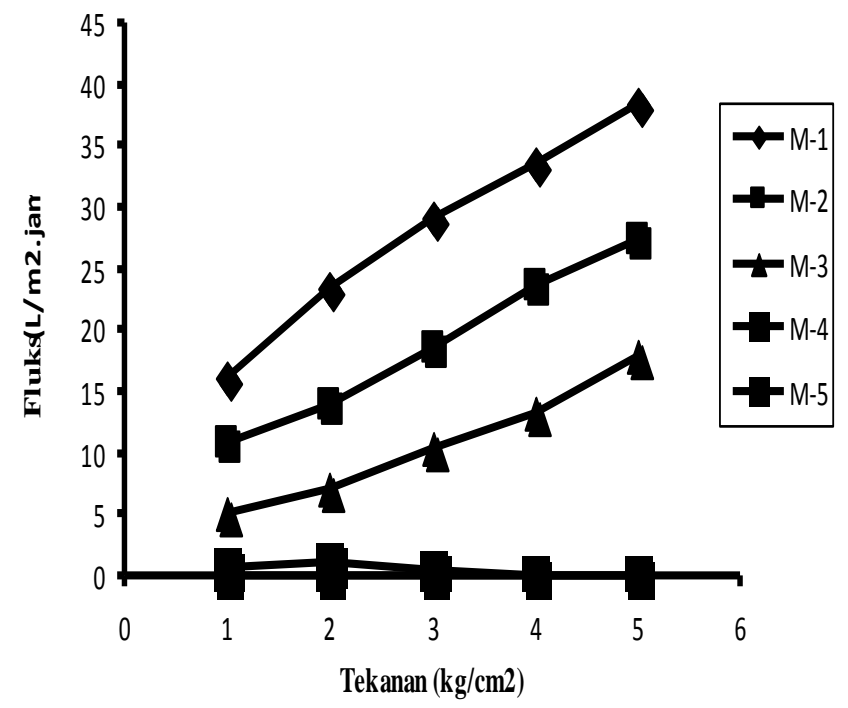

Gambar 2. Grafik perbandingan nilai fluks pada membran 1\%, 2\%, 3\%. 
Konsentrasi polimer pembentuk membran juga sangat mempengaruhi karakter membran yang terbentuk, semakin tinggi konsentrasi polimer pembentuknya maka membran yang dihasilkan akan semakin padat sehingga fluks membran akan semakin kecil (Mulder, 1996). Pada pembuatan membran dalam penelitian ini konsentrasi kitosan akan mempengaruhi nilai fluks dari membran. Gambar 2 merupakan grafik yang menunjukkan perbandingan nilai fluks pada membran $1 \%, 2 \%$, dan $3 \%$.

Pada membran kitosan $4 \%$ terjadi fenomena yang berbeda. Pada membran tersebut fluks naik pada tekanan 1-2 $\mathrm{kg} / \mathrm{cm}^{2}$, kemudian fluks turun seiring bertambahnya tekanan, bahkan pada tekanan 4-5 $\mathrm{kg} / \mathrm{cm}^{2}$ tidak dihasilkan permeat. Hal ini disebabkan oleh tingginya konsentrasi kitosan dalam membran, sehingga membran yang terbentuk semakin padat dan fluks membran semakin kecil.

Selain karena tingginya konsentrasi kitosan dalam membran, turunnya nilai fluks seiring bertambahnya tekanan disebabkan oleh terjadinya kompaksi membran. Kompaksi membran merupakan suatu perubahan mekanik pada struktur membran polimer yang terjadi akibat gaya dorong. Akibatnya semakin tinggi tekanan yang diberikan, maka kompaksi membran akan berlangsung lebih cepat (Mulder, 1996). Ketika terjadi kompaksi, struktur membran kitosan 4\% menjadi lebih kompak dan pori-pori membran merapat sehingga menghasilkan penurunan nilai fluks, bahkan setelah relaksasi dengan cara menurunkan tekanan pada proses, nilai fluks tidak dapat kembali sebagaimana nilai awalnya, karena gejala ini bersifat tidak dapat balik (Irreversible).

Untuk membran kitosan 5\%, pada tekanan $1-5 \mathrm{~kg} / \mathrm{cm}^{2}$ tidak dihasilkan permeat. Hal ini disebabkan karena konsentrasi kitosan dalam membran terlalu tinggi sehingga molekul dalam membran sangat rapat, maka membran yang terbentuk terlalu padat dan tidak dapat menghasilkan permeat walaupun dengan adanya gaya dorong.

\section{Pengukuran Koefisien Rejeksi}

Nilai koefisen rejeksi membran semakin tinggi dengan bertambahnya konsentrasi kitosan dalam membran. Pada membran yang sama, semakin tinggi tekanan yang diberikan menghasilkan nilai koefisien rejeksi yang makin kecil. Hal tersebut disebabkan karena adanya gaya dorong yang besar menimbulkan deformasi pada membran, sehingga ukuran pori-pori membran melebar dan partikel-partikel rhodamin B yang seharusnya tertahan dapat lolos melewati membran.

Koefisien rejeksi membran kitosan $3 \%$ lebih tinggi daripada membran kitosan $1 \%$ dan $2 \%$. Hal ini disebabkan oleh ukuran dan jumlah pori-pori membran. Membran 3\% memiliki jumlah pori-pori yang lebih sedikit serta ukuran pori-porinya lebih kecil dari membran $1 \%$ dan $2 \%$, sehingga makin banyak molekul rhodamin B yang tertahan, akibatnya koefisien rejeksinya juga makin tinggi. Pada membran kitosan $4 \%$, fluks yang dihasilkan nilainya sangat kecil sehingga tidak diukur koefisien rejeksinya karena dianggap sebagai membran gagal. Begitu juga untuk membran kitosan $5 \%$, pada membran ini tidak dihasilkan permeat sehingga tidak dapat pula diukur koefisien rejeksinya. 


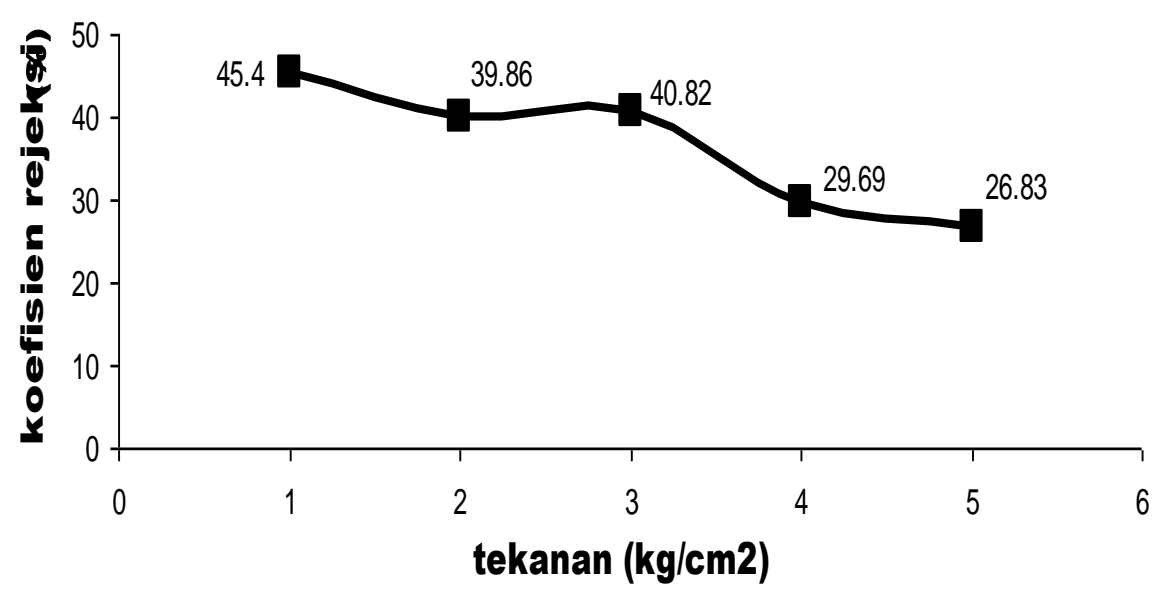

(a)

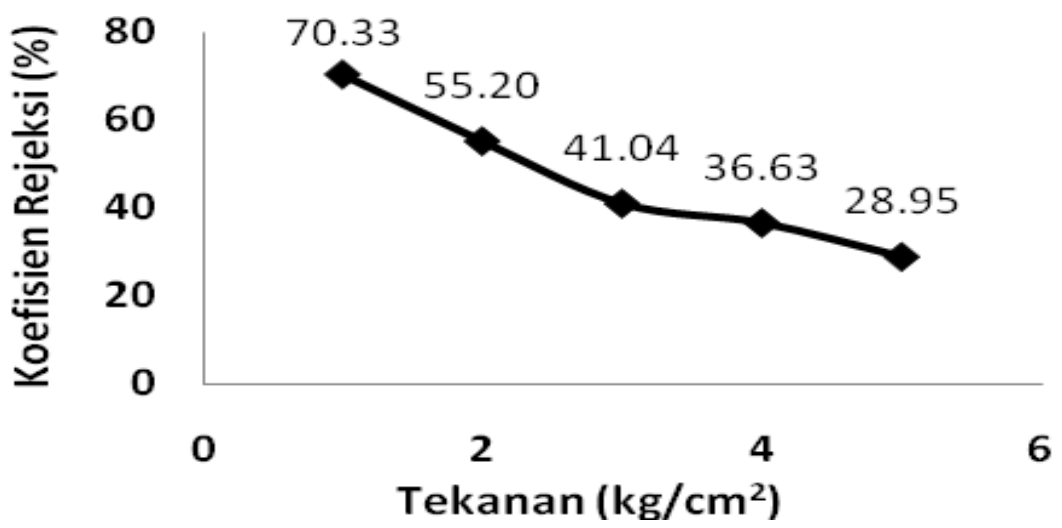

(b)

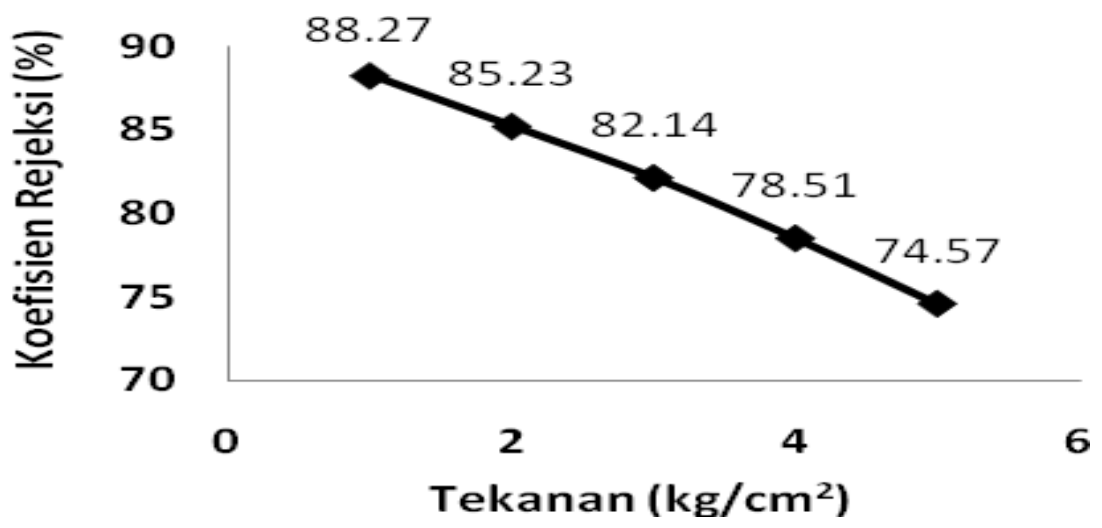

(c)

Gambar 3.Grafik Hubungan Tekanan Operasional dan Koefisien Rejeksi pada

(a) Membran Kitosan 1\%; (b) Membran Kitosan 2\%; (c) Membran Kitosan 3\%. 
Pembuatan dan uji kemampuan membran kitosan... (Nita Kusumawati dan Septiana Tania)

\section{KESIMPULAN}

Berdasarkan hasil penelitian yang telah dilakukan, dapat diambil suatu kesimpulan bahwa :

1. Bertambah tingginya konsentrasi kitosan, membran memiliki daya tegang dan regang yang tinggi. Nilai tegangan (Load) yang diperoleh sebesar 0,1531-2,8571 kgf dan nilai regangan (Stroke) sebesar 2,86-5,48\%. Membran yang dihasilkan (1-3\%) masuk dalam rentang membran ultrafiltrasi.

2. Pada membran yang sama, semakin besar tekanan yang diberikan menghasilkan fluks yang besar. Semakin besar konsentrasi kitosan dalam membran akan menghasilkan fluks yang kecil. Nilai fluks rhodamin B yang dihasilkan oleh membran kitosan $1 \%, 2 \%$ dan 3\% berturut-turut adalah $\quad 16,052-38,372 \quad \mathrm{~L} / \mathrm{m} 2 . j \mathrm{am}$; 10,875-27,446 L/m2.jam dan 5,074-17,801 L/m2.jam. Sedangkan membran kitosan $4 \%$ dan $5 \%$ dianggap sebagai membran gagal.

3. Nilai koefisien rejeksi yang dihasilkan oleh membran kitosan $1 \%$, $2 \%$ dan $3 \%$ secara berturut-turut yaitu 26,83-45,40\%; 28,95-70,33\% dan $74,57-88,27 \%$. Nilai koefisien rejeksi semakin besar dengan bertambahnya konsentrasi kitosan. Bertambahnya tekanan operasi pada jenis membran yang sama menghasilkan nilai rejeksi yang semakin menurun.

\section{DAFTAR PUSTAKA}

Astuti, Puji, 2007, Adsorbsi Limbah Zat Warna Tekstil Jenis Procion Red MX 8B oleh Kitosan dan Kitosan Sulfat Hasil Deasetilasi Kitin Cangkang Bekicot (Achatina Fullica), Skripsi, Fakultas MIPA, Universitas Sebelas Maret, Surakarta.
Cahyaningrum, S.E., 2001, Karakterisasi Adsorpsi Ni (II) dan Cd (II) pada Kitosan dan Kitosan Sulfat dari Cangkang Udang Windu (Penaus Monodon), Tesis, UGM, Jogjakarta.

Chatterjee D., R.P., Vidya, \& S., Anindita, 2007, Kinetics of The Decoloration of Reactive Dyes Over Visible LightIrradiated $\mathrm{TiO} 2$ Semiconductor Photocatalyst, Journal of Hazardous Materials, Vol. 156, 435-441. Elsevier.

Christie, R.M., 2001, Colour Chemistry, RSC Paperback, The Royal Society of Chemistry, UK.

Fisher P, D., Algar \& J., Sinagra, 1999, Use of Rhodamine B as A Systemic Bait Marker For Feral Cats (Felis catus), Wildlife Research, Vol. 26, 281-285.

Isminingsih, L., Djufri, \& Rassid,1982, Pengantar Kimia Zat Warna, Institut Teknologi Tekstil, Bandung.

J.C.Y.Ng, W.H., Cheung, \& G., McKay, 2003, Equilibrium Studies for The Sorption of Lead From Effluents Using Chitosan, Chemosphere, Vol.52, 1021-1030.

Kim, J.H., \& K.W., Lee, 1998, Effect of PEG Additive On Membrane Formation By Phase Inversion, Journal of Membrane Science, Vol. 138, 153-163.

Kusumawati, Nita, 2009, Pemanfaatan Limbah Kulit Udang sebagai Bahan Baku Pembuatan Membran Ultrafiltrasi, Inotek, Vol. 13, No. 2.
Kusumawati, Nita, 2009, Spektrofotometri UV-Vis, Unesa press, Surabaya.

Liu, J., 2003, Preparation and Characterization of Chitosan/Cu (II) Affinity Membrane for Urea Adsorption, Journal of Applied 
Polymer Science, Vol. 90, 1108-1112.

Robert, G.A.F., 1992, Chitin Chemistry, Londo, The MacMillan Press.

Malleviale, J., 1996, Water Treatment Membran Processes. AWWA, Lyonnaise des Eaux, Water Research Commision of South Africa. New York: Mc Graw Hill.

Meriatna, 2008, Penggunaan Membran Kitosan Untuk Menurunkan Kadar Logam Krom (Cr) dan Nikel (Ni) dalam Limbah Cair Industri Pelapisan Logam, Tesis, Sekolah Pascasarjana Teknik Kima, Universitas Sumatera Utara.

Mulder, M., 1991, Basic Principles of Membran Technology, Netherlands, Khewer Academic Publisher.

Rahayu, L.H. \& S., Purnavita, 2007, Optimasi Pembuatan Kitosan Dari Kitin Limbah Cangkang Rajungan (Portunus pelagicus) Untuk Adsorben Ion Logam Merkuri, Reaktor, Vol. 2, No. 1.

Rismana, E., 2004, Serat Kitosan Mengikat Lemak, Kompas, (http://www.kompas.com/komposcetak/0301/09/iptek/60155.htm).

Diakses Tanggal 5 Agustus 2010.

Salami, L., 1998, Pemilihan Metode Isolasi Khitin dan Ekstraksi Khitosan dari Limbah Kulit Udang Windu (Phenaeus monodon) dan Aplikasinya sebagai Bahan Koagulasi Limbah Cair Industri Tekstil, Karya Utama Sarjana Kimia, Jurusan Kimia F MIPA UI, Jakarta.

Silva, S.S., 2005, Physical Properties and Biocompatibility of Chitosan/Soy

Stephenson, T., S., Judd, B., Jeffresin, \& K., Brindle, 2002, Membran Bioreactor for Wastewater Treatment. IWA Publishing, London.

Rathke, T.D., \& S.M., Hudson, 1994, Review of Chitin and Chitosan as Fiber and Film Formers, Macromol. Chem. Phys., C, Vol. 34, No. 3, 375-473.

Umeda, M., 1956, Experimental study of xanthene dyes as carcinogenic agents. Gann 47-51.s 